\title{
THE URINARY TRACT IN MYELO-MENINGOCELE
}

\author{
By Drs. L. Bernstein-Hahn, J. B. Cibeira and J. Zonzini \\ Instituto Nacional de Rehabilitacion al Lisiado, Buenos Aires, Argentine
}

(Paper presented by Dr. CibeIRA)

THE improved methods of treatment of children with myelo-meningocele has shifted the care of them to rehabilitation centres, orthopaedic surgeons and urologists, the latter have an increasing role to play in their social acceptancy and life expectancy.

In our National Institute of Rehabilitation, a special spina bifida clinic has been started with the co-operation of physiatrists, psychiatrists, orthopedists, urologists and genetists to improve the management of these patients.

In nearly two years we have evaluated $5 \mathrm{I}$ patients with spina bifida myelocele and myelo-meningocele, of whom 46 have been operated soon after birth. findings:

On admission, 45 intravenous pyelograms were performed with the following

Urographic findings in 46 patients with myelo-meningocele:

Age Total number

Results

\begin{tabular}{|c|c|c|}
\hline to I year & 4 & 4 normal \\
\hline I to 2 & 2 & 2 normal \\
\hline 3 to 5 & I3 & 7 normal \\
\hline 5 to 8 & 6 & $\begin{array}{l}5 \text { normal upper tract with ureteral dilatation } \\
4 \text { normal } \\
\text { I normal upper tract with ureteral dilatation } \\
\text { I bilateral hydronephrosis }\end{array}$ \\
\hline 8 to $\mathrm{I} 2$ & I I & $\begin{array}{l}2 \text { normal } \\
2 \text { poor upper tract visualisation } \\
3 \text { dilatation of pelvis and ureter } \\
2 \text { hydronephrosis } \\
2 \text { non-visualisation }\end{array}$ \\
\hline I3 to I6 & 7 & $\begin{array}{l}2 \text { normal } \\
\text { I normal upper tract with dilatation of ureter } \\
\text { I poor upper tract visualisation, dilatation of ureter } \\
\text { I hypotonic pelvis, dilatation of ureter } \\
2 \text { hydronephrosis }\end{array}$ \\
\hline over I6 & 3 & $\begin{array}{l}\text { I bilateral hydronephrosis } \\
2 \text { non-visualised upper tract }\end{array}$ \\
\hline
\end{tabular}

Cystographic findings in 30 patients were as follows:

Age Total number

Results

\begin{tabular}{|c|c|c|}
\hline I to 2 & I & I well outlined bladder \\
\hline 3 to 5 & 9 & $\begin{array}{l}4 \text { trabeculated bladder } \\
2 \text { small spastic bladder }\end{array}$ \\
\hline 5 to 8 & 2 & $\begin{array}{ll}3 & \text { ureteral reflux } \\
2 & \text { trabeculated } \\
\text { I } & \text { small bladder } \\
\text { I } & \text { massive bilateral reflex }\end{array}$ \\
\hline
\end{tabular}


Age

Total number

Results

8 to $\mathrm{I} 2$

9 I small bladder

5 unilateral ureteral reflux

over I6

3 massive bilateral reflux

9

5 small bladder

I trabeculated bladder

3 unilateral ureteral reflux

So far, eleven patients were submitted to urinary diversion procedures to prevent further renal damage and provide a more socially acceptable answer to their incontinence.

Surgical Procedure, Tubeless Cystostomy:

\begin{tabular}{|c|c|c|c|c|}
\hline Case No. & Age & $\begin{array}{l}\text { Neurological } \\
\text { diagnosis }\end{array}$ & $\begin{array}{l}\text { Pre-op. intravenous } \\
\text { urography }\end{array}$ & $\begin{array}{l}\text { Pre-op. retrograde } \\
\text { cystography }\end{array}$ \\
\hline 4 L. B. & 6 & $\begin{array}{l}\text { Meningocele op. } \\
\text { at birth. }\end{array}$ & $\begin{array}{l}\text { Normal upper } \\
\text { tract. } \\
\text { Big trabeculated } \\
\text { bladder. }\end{array}$ & $\begin{array}{l}\text { Piriform bladder, } \\
200 \text { c.c. capacity. }\end{array}$ \\
\hline & I I & $\begin{array}{l}\text { Meningocele op. } \\
\text { at birth. }\end{array}$ & $\begin{array}{l}\text { Pelvic dilatation } \\
\text { of ureter. }\end{array}$ & $\begin{array}{l}\text { Bilateral ureteral } \\
\text { reflux. }\end{array}$ \\
\hline I6 L. M. & 4 & $\begin{array}{l}\text { Myelo-meningo- } \\
\text { cele and hydro- } \\
\text { cephalia op. }\end{array}$ & Normal. & $\begin{array}{l}\text { Big piriform } \\
\text { bladder. }\end{array}$ \\
\hline 23 E. A. & 3 & $\begin{array}{l}\text { Meningocele op. } \\
24 \text { hr. after birth. } \\
\text { Hydrocephalus op. }\end{array}$ & $\begin{array}{l}\text { Unilateral hydro- } \\
\text { nephrosis with a } \\
\text { non-functioning } \\
\text { kidney. }\end{array}$ & $\begin{array}{l}\text { Small trabeculated } \\
\text { bladder. }\end{array}$ \\
\hline 32 J. M. R. & I6 & $\begin{array}{l}\text { Spina bifia. } \\
\text { Meningocele op. } \\
\text { age } 2 .\end{array}$ & $\begin{array}{l}\text { Poor upper tract. } \\
\text { Visualisation. }\end{array}$ & $\begin{array}{l}\text { Well contoured } \\
\text { medium-capacity } \\
\text { bladder. }\end{array}$ \\
\hline
\end{tabular}

Uretero-ileostomy by Bricker's Method:

\begin{tabular}{|c|c|c|c|c|}
\hline Case No. & Age & $\begin{array}{l}\text { Neurological } \\
\text { diagnosis }\end{array}$ & $\begin{array}{l}\text { Urographic } \\
\text { findings }\end{array}$ & $\begin{array}{l}\text { Cystographic } \\
\text { findings }\end{array}$ \\
\hline 6 E. S. & 8 & $\begin{array}{l}\text { Myelo-meningo- } \\
\text { cele op. age } 8 \text {. }\end{array}$ & $\begin{array}{l}\text { Unilateral hydro- } \\
\text { nephrosis and } \\
\text { non-functioning } \\
\text { kidney. }\end{array}$ & $\begin{array}{l}\text { Massive reflux in } \\
\text { a non-function- } \\
\text { ing kidney. }\end{array}$ \\
\hline I8 O. A. & 9 & $\begin{array}{l}\text { Myelo-meningo- } \\
\text { cele. }\end{array}$ & Non-visualisation. & $\begin{array}{l}\text { Massive bilateral } \\
\text { reflux. }\end{array}$ \\
\hline I9 S. C. & 9 & Meningocele op. & $\begin{array}{l}\text { Bilateral hydro- } \\
\text { nephrosis. }\end{array}$ & $\begin{array}{l}\text { Massive bilateral } \\
\text { reflux. }\end{array}$ \\
\hline 3I E. L. & 5 & $\begin{array}{l}\text { Myelo-meningo- } \\
\text { cele op. }\end{array}$ & $\begin{array}{l}\text { Not performed } \\
\text { because of aller- } \\
\text { gic reaction. }\end{array}$ & Bilateral reflux. \\
\hline 4I B. M. & 18 & $\begin{array}{l}\text { Myelo-meningo- } \\
\text { cele op. at } 4 \text { days } \\
\text { of age. }\end{array}$ & $\begin{array}{l}\text { Unilateral hydro- } \\
\text { nephrosis, ureter } \\
\text { dilatation. }\end{array}$ & Unilateral reflux. \\
\hline
\end{tabular}


Ileo-cystostomy by Cordonier's Method:

\begin{tabular}{|l|c|c|c|c|}
\hline Case No. & Age & \multicolumn{1}{|c|}{$\begin{array}{c}\text { Neurological } \\
\text { diagnosis }\end{array}$} & \multicolumn{1}{|c|}{$\begin{array}{c}\text { Urographic } \\
\text { findings }\end{array}$} & \multicolumn{1}{c|}{$\begin{array}{c}\text { Cystographic } \\
\text { findings }\end{array}$} \\
\hline Io E. B. & 6 & $\begin{array}{c}\text { Myelo-meningo- } \\
\text { cele op. at 24 hr. } \\
\text { after birth. }\end{array}$ & Normal. & No reflux. \\
\hline
\end{tabular}

Nephrostomy:

\begin{tabular}{|c|c|c|c|c|}
\hline Case No. & Age & $\begin{array}{c}\text { Neurological } \\
\text { diagnosis }\end{array}$ & $\begin{array}{c}\text { Urographic } \\
\text { findings }\end{array}$ & $\begin{array}{c}\text { Cystographic } \\
\text { findings }\end{array}$ \\
\hline 30 M. C. D. & Io & $\begin{array}{c}\text { Myelo-meningo- } \\
\text { cele op. at 3 } \\
\text { months of age. }\end{array}$ & Non-visualisation. & $\begin{array}{c}\text { Megabladder and } \\
\text { massive bilateral } \\
\text { reflux. }\end{array}$ \\
\hline
\end{tabular}

The review of the urological status of $5 \mathrm{I}$ patients with myelocele and myelomeningocele shows an increased deterioration of renal function after the age of 8 , although most probably we did not get the most severe early cases. We must follow-up these patients for early detection and adequate treatment of renal function impairment.

\section{Discussion}

Cosbie Ross, $\mathcal{F}$., said this paper raised many interesting points and he was quite sure as Dr. Cibeira said that urinary diversion in these cases was sometimes a life-saving procedure. His first question related to follow-up period. He had found it necessary to follow up these cases indefinitely, and in one case the patient developed trouble with one of her kidneys five years after the operation had been carried out. It was important to follow up these cases not only for stone formation and renal failure even for long periods of time. One could then deal with troubles as they arose. Secondly, he understood that Dr. Cibeira carries out nephrostomy in some of these cases. He always regarded it as a temporary operation, he found it very difficult and it was not an operation he liked. One must do it occasionally as an emergency but he always regarded it as of temporary character. He would like to ask Dr. Cibeira whether he regarded it in such a light and whether he changed over to some other form of collection of urine less injurious to the kidneys at a later stage and easier to deal with by the patient.

Cibeira, $\mathcal{F}$., agreed that he had not had much experience and he would try to follow up the patients. He realised that it was very important. Many of the patients were in the interior part of the country and sometimes it was very difficult to get patients back, and eventually one had to ask the Government to pay for the trip of these patients to come to the city for carrying out the follow up. They had done the operation for only about I year 6 months which is why he did not comment upon their results. With reference to the second question, he considered it a life saving procedure with his patient with a huge hydronephrosis and being in very bad shape.

Chantraine, $A$. (Belgium), said he would like to know if the speaker had had experience with electromyography of the muscles of the sphincter. He mentioned electromyography in the investigations.

Cibeira, $\mathcal{F}$., replied that he found in two patients by electromyography a spastic type

\section{0}


of sphincter of the anus and he was sure that all meningoceles were not the same. There were high types, middle types and low types.

Chantraine, $A$., said that even if they had different heights, in the study he had made in New York with other colleagues in 53 patients, he had never found spastic sphincters, they usually were very flat. They found fibrillation, fasciculation or sometimes a patient who preserved a very good conus medullaris in a very small lesion, they found a good automatic response of the sphincter, but they never found any spastic response.

Michaelis, L. (England), said one seemed now to accept that the Brikker bladder was a permissible operation. He thought that it was not. The few experiences at Stoke Mandeville with it were unsatisfactory. One patient died, another had to have two laparotomies for ileus caused by adhesions having formed after this operation. So, one should consider very carefully what would happen later. Dr. Cibeira, for local reasons, had great difficulties in getting his children at a much earlier age, and once he was able to do so he might not have had to consider this dangerous and mutilating operation at all. He asked whether it would not be better in such rare cases to transplant the lower ends of the ureters into the abdominal wall. This operation, which leaves the peritoneum and the bowel alone, was certainly much safer and just as effective as the ileal bladder.

Cosbie Ross, $\mathcal{F}$., reminded Dr. Michaelis that the word diversion of the urine included the operation which he had just accepted-in other words the ureterostomy.

Guttmann, L., agreed with Mr. Cosbie Ross that one had indeed to be very selective in one's choice which kind of diversion one was going to use. As far as he could see from the literature, the ileal bladder seemed to be more successful in children than in adults, but Dr. Michaelis was right to draw attention to the dangers of the ileal bladder and he thought it was terrible if a patient came back with an ileus and was operated sometimes too late and had to die.

Walsh, $\mathcal{F}$. (England), thought the Lapides vesicostomy was preferable, from a longterm point of view, to an ileal loop, because the time would come when the patient was admitted as an emergency. One would wonder whether he had a pyelonephrosis or an obstructed ureter and one would be unable to investigate it properly with an ileal loop bladder.

Cibeira, $\mathcal{F}$., said with a small bladder he preferred the type of operation mentioned by Dr. Michaelis, but cystostomy had its indications. It was better to do the cystostomy, but if one had a big hydronephrosis and a very small trabeculated bladder, it was very difficult to do a cystostomy.

\title{
PHENOL SPINAL BLOCKS
}

\author{
J. C. Dominelli, M.D., M. Fernandez, M.D., and E. Apolinario, M.D. \\ National Rehabilitation Center, Buenos Aires, Argentine
}

(Paper presented by Dr. Sotelano)

THE authors report their experience on the treatment of severe spasticity with the use of intrathecal phenol blocks.

A short review of surgical and non-surgical procedures is given, and spasticity is evaluated with regard to its influence upon urinary tract function and its interference with A.D.L.

Details of 15 cases are given about the level of lesion, an etiology, type of spasticity, type of bladder, interference of free circulation of C.S.F., and the results of unilateral or bilateral spinal blocks. 